\title{
Papillary cystadenoma of the lacrimal caruncle
}

\author{
C. H. GREER \\ Royal Victorian Eye and Ear Hospital, Melbourne, Australia
}

The following case is presented as an additional example of papillary cystadenoma of the lacrimal caruncle.

\section{Case report}

A 68-year-old white woman presented with an irritable and slightly enlarged left ${ }^{\top}$ caruncle. What was clinically described as a pedunculated caruncular papilloma was excised and sectioned.

Microscopic appearances Sections showed part of a spherical cystadenoma situated immediately beneath the surface epithelium of the caruncle (Fig. I).

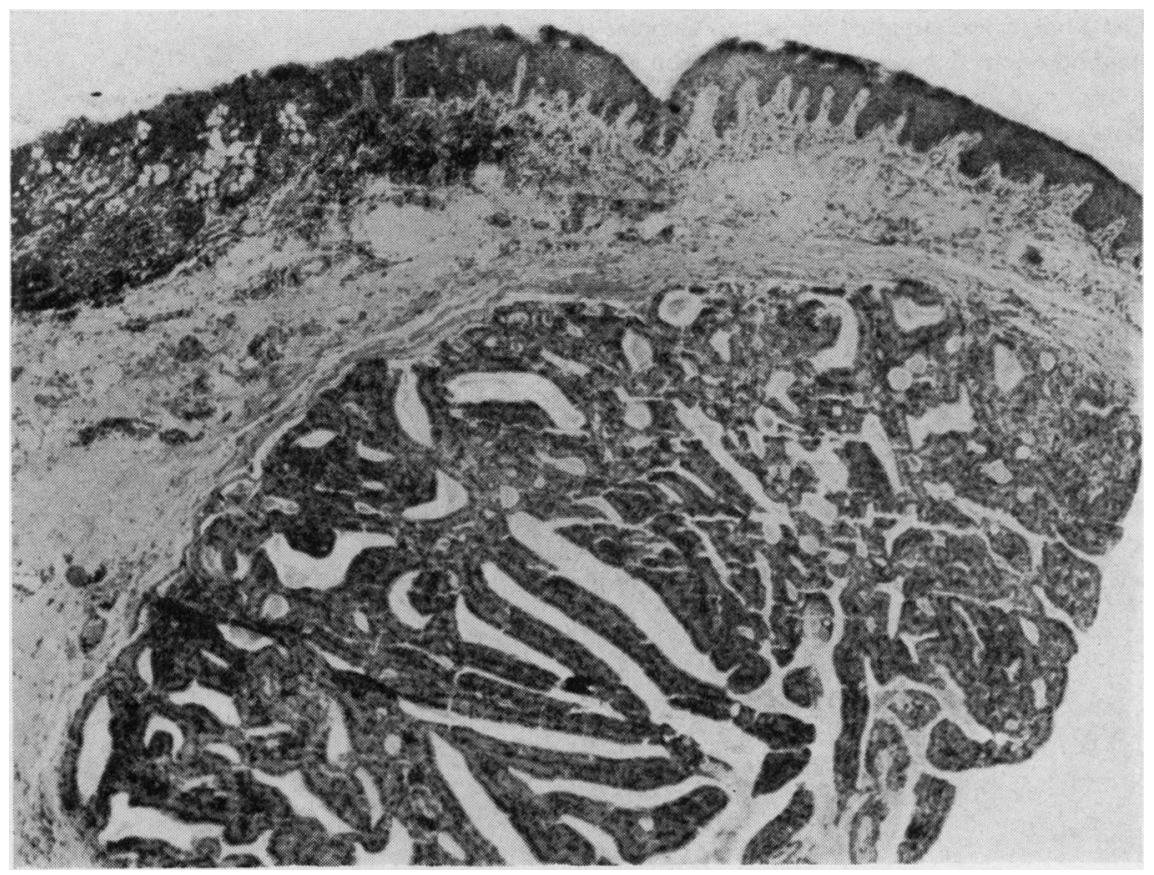

FIG. I Low-power view of papillary cystadenoma of the caruncle. Haematoxylin and eosin $\times 18$

The adenoma, which was sharply circumscribed but not encapsulated, consisted in part of radiallyorientated, slender, anastomosing papillary processes clothed by double-layered eosinophilic epi- $\frac{O}{\mathbb{D}}$ thelium (Fig. 2). The basal cells of this epithelium were polygonal and relatively small with round $\stackrel{\stackrel{\rho}{\mathbb{Q}}}{\mathbb{Q}}$ nuclei, while the surface cells were tall and cylindrical in shape with conspicuous cell boundaries, granular eosinophilic cytoplasm, and oval nuclei lying near the free borders of the cells (Fig. 3). 


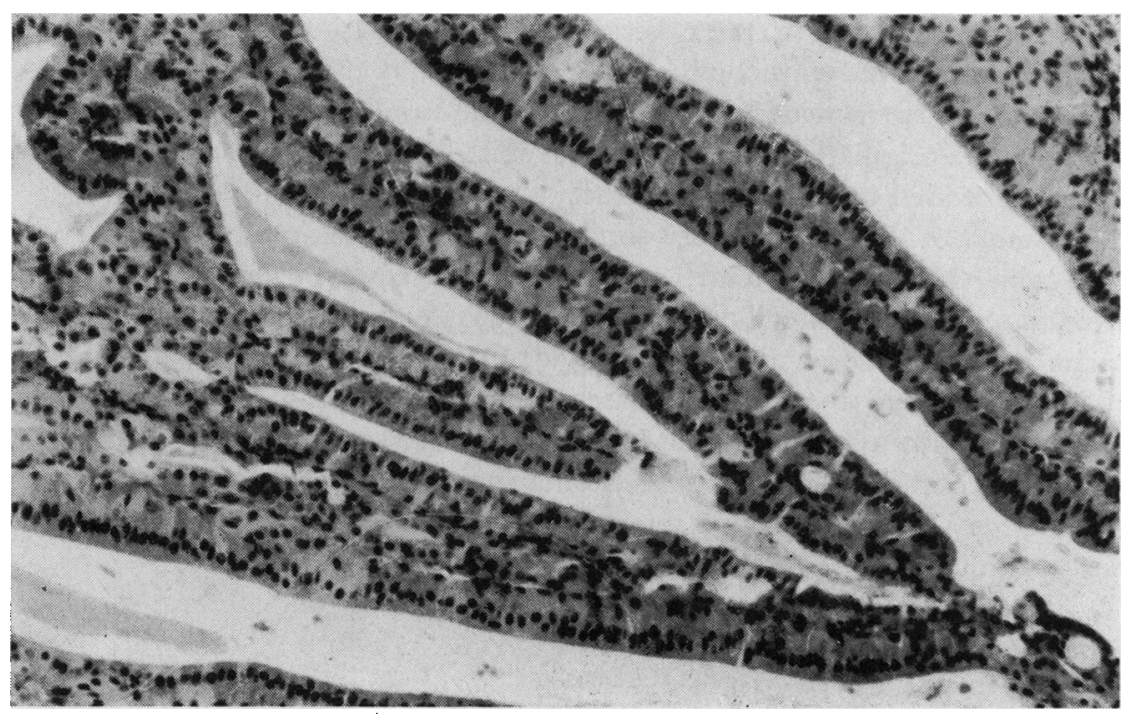

FIG. 2 Higher magnification of the papillary processes, with inconspicuous fibrous tissue cores.

Haematoxylin and eosin $\times 75$

Some of these cells contained mucus. The inconspicuous connective tissue stroma of the growth was sparsely infiltrated by lymphocytes. Other areas of the adenoma were more compact and exhibited tubules and acini containing blobs of mucus. The tumour had not been completely removed.

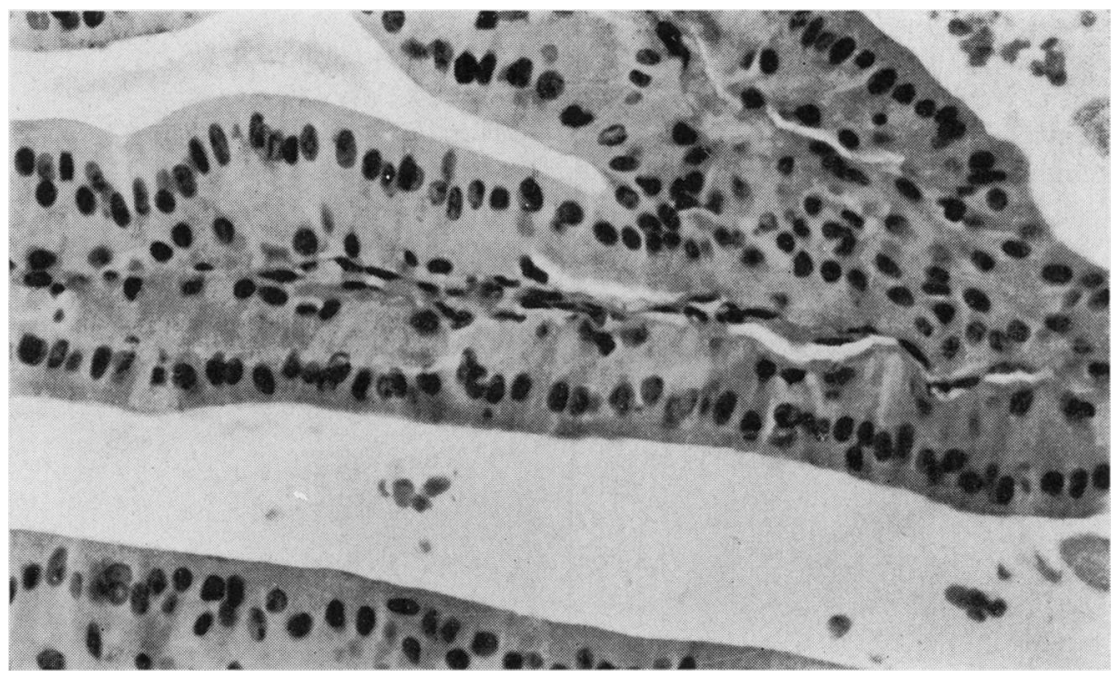

FIG. 3 Papillary processes clothed by characteristic double-layered epithelium. Haematoxylin and eosin $\times 180$

\section{Comment}

The epithelial component of this adenoma is strikingly similar to that seen in adenolymphomata of the parotid gland. Adenolymphomata (papillary cystadenoma lymphomatosum, Warthin's tumour) are benign tumours occurring predominantly in the substance 
of, or in close relation to, the parotid gland. They are made up of characteristic double layered eosinophilic epithelium clothing richly cellular lymphoid stroma. Azzopardi ang Hou (1964) have provided striking proof of the validity of the prevailing belief that aden $\overrightarrow{\sigma^{2}}$ lymphomata originate from salivary duct epithelium incorporated in lymph nodes adjace to, or embedded in, the parotid gland.

Tumours of identical or very similar structure occasionally arise from minor salivaris glands in the larynx (Heinz, 1951) and oral cavity (Veronesi and Corbetta, I96\%, Goldmann, 1967; Stuteville and Corley, 1967) or from the minor lacrimal glands of the caruncle (Mackenzie and Patience, 1959; Oaks and Jenson, 1963; Forbes and Crawfor雨 I963). Coats ( 1912 ) reported a case which he called spiradenoma papilliferum cysticum on the mistaken assumption that it arose from a sweat gland. In extraparotid cystaden $\Theta^{\omega}$ mata the characteristic lymphoid stroma may be scanty or absent and the usual fibrot capsule may be missing. No report of an adenolymphoma of the major lacrimal glands has yet appeared.

\section{Summary}

A papillary cystadenoma of the lacrimal caruncle in a woman aged 68 years is reported The growth probably originated in accessory lacrimal glands.

\section{References}

Azzopardi, J. G., and hou, L. T. (1964) F. Path. Bact., 88, 2 I 3

COATs, G. (1912) Roy. Lond. Hosp. Rep., 18, 269

FORBES, G. B., and GRAWFORD, R. A. D. (1963) Brit. F. Ophthal., 47, 177

goldman, R. L. (1967) Amer. F. clin. Path., 48, 49

HEINZ, I. (1951) Aust. N.Z. F. Surg., 21, 47

mackenzie, J. R., and PATIENCE, C. R. (1959) F. Path. Bact., 78, 288

OAKs, L. W., and Jenson, м. B. (1963) Amer. F. Ophthal., 56, 459

STUteVille, O. H., and CORLey, R. D. (1967) Cancer (Philad.), 20, I578

VERONESI, U., and CORBETTA, L. (1960) Acta oto-laryng. (Stockh.), 52, I 